\title{
人口流出地区城镇化路径机制再认识 以四川省县域单元为例
}

\author{
肖磊, 潘 劼
}

(中国城市规划设计研究院西部分院,重庆 401120)

\begin{abstract}
摘 要: 论文以四川省县域单元为研究对象, 探讨了人口流出地区城镇化发展的特征与机制。研究发现, 不同于沿 海地区, 四川省县域城镇化以生活为主导, 农民进城的目标以生活与教育为主, 而非进城务工。进城人群的主体是 劳动力大量流失后剩下的留守人群, 进城生活的经济来源相当程度上依赖外出劳动力打工收人的返还。在产业支 撑城镇化能力较弱的同时, 形成了异地工业化带动本地城镇化的特殊模式。在特殊的人口进城机制影响下, 人口 流出地区往往呈现特殊的城镇化表现, 如人口流出越多, 城镇化速度越快, 县城可以脱离制造业而繁荣发展, 县域 城镇人口增速远超过地级市等。基于新的认识, 研究对城镇化机制相关认识进行了探讨, 并就此类地区城镇化发 展的长期趋势、潜在问题进行了展望。
\end{abstract}

关 键 词: 城镇化机制; 县域; 人口流出;四川省

改革开放 $40 \mathrm{a}$ 来, 中国城镇化取得了显著进 展, 2017年城镇化率已达 $58.5 \%$ 。中国既有文献关 于城镇化的研究十分丰富,城镇化特征分析方面: 一是侧重于城镇化过程中的现象, 研究城镇化水平 阶段、地区之间快慢差异、人口流动方向意愿等 ${ }^{[1-5]}$; 二是识别城镇化中存在的重要问题,包括流动人口 生活水平 ${ }^{[6]}$ 、接受公共服务情况 ${ }^{[7]}$ 等, 并就各专项问 题进行深人探讨。城镇化机制研究方面:一般将工 业化看作城镇化的主导因素 ${ }^{[8-9]}$,或根据不同地区产 业发展情况探讨地方城镇化动力模式, 如重工业主 导模式 ${ }^{[10]}$ 、旅游业主导模式 ${ }^{[11]}$ 等; 部分研究采用定量 统计方法, 探讨对城镇化发展快慢的影响因素, 包 括经济、社会、地形、交通、生态环境等 ${ }^{[12-14]}$ 。城镇化 发展机理方面, 主要关注城镇化的时空特征 ${ }^{[15]}$ 、空

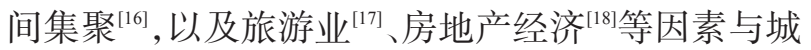
镇化的作用关系等。

虽然当前研究成果较多, 但也存在如下特点:一 是对人口流出地区的城镇化研究较少, 既有研究相 对侧重省级和地市单元 ${ }^{[19-23]}$ 以及中东部省份 ${ }^{[24-26]}$;
是对典型人口流出地区的城镇化机制过程解读较 少, 相关研究多侧重经济层面的分析 ${ }^{[27-29]}$, 对人口城 镇化具体过程与机制解析涉及较少。

四川是西部人口流出大省, 其县域单元最为典 型。本文以四川县域为研究对象, 识别其城镇化发 展特征, 对人口城镇化的路径、机制进行梳理, 从而 对人口流出地区城镇化模式进行新的解读。

\section{1 研究思路、研究区及数据}

\section{1 研究思路}

基于人口流出地区城镇化问题的复杂性, 本文 采用复合型方法来开展研究:一是根据 2000-2015 年的统计数据进行分析, 研究四川省县域城镇化的 基本特征,通过不同层级的城镇化情况对比,分析 此类地区不同于常规经验的人口城镇化、经济发展 规律; 二是典型区县案例研究, 结合现场调研, 深人 剖析案例地区的城镇化情况, 提炼总结出此类地区 城镇化的典型特征,并论述阐明形成这些特征的原

收稿日期: 2019-04-08; 修订日期: 2019-10-21。

基金项目: 中国城市规划设计研究院科技创新基金项目。[Foundation: Project of Science and Technology Innovation Foundation of China Academy of Urban Planning and Design. ]

第一作者简介: 肖磊(1985- ), 男,江苏泰州人,硕士,城市规划师,主要研究方向为城市规划。E-mail: 76893656@qq.com 
因和机理。

\section{2 研究区概况与数据来源}

研究选取四川省除成都、攀枝花、三州地区(甘 孜、阿坝、凉山) 以外的 76 个县(县级市)作为研究对 象(表 1)。主要考虑: (1) 所选择县以农业县为主, 跨 越了不同地形单元, 对人口流出地区具有较强的代 表性; (2)成都市并非人口流出地区, 不纳人研究范 围; (3) 各地级市市区人口流人与流出情况比较复 合, 典型性不明显, 不纳人研究范围; (4) 其他地区的 情况比较特殊, 甘孜与阿坝州人口稀少且为人口流 人地区, 不纳人研究范围; 凉山州与攀枝花气候不 同于四川盆地, 人口流动的情形较为特殊, 本文暂 不纳人。

从地形上来看, 研究区内 76 个县主要是丘陵 县, 少部分为平原县和山地县。从主导产业来看, 多为具有一定工业基础的农业县, 另有少数旅游 县, 这与一般人口流出地区的总体情形相似。2015 年各县平均常住人口 53.5 万人, 平均净流出人口规 模为 14.2 万人, 平均城镇化率为 $37.5 \%$ 。

本文以苍溪县作为典型案例进行分析, 苍溪县 隶属四川省广元市, 地处四川盆地北缘, 大巴山南 麓之低、中山丘陵地带, 2015 年净流出人口规模占 户籍人口比重为 $23.7 \%$, 城镇化率达到 $32.0 \%$ 。苍 溪县作为四川省典型农业丘陵县, 人口流出情况接 近全省县域平均水平, 具有明显的代表性。

本文主要指标数据, 包括GDP、工业总产值、各 项人口数据、在校学生数等, 来源于《四川统计年 鉴》(2001、2011、2016)、《2000年第五次全国人口普 查主要数据》《2010年第六次全国人口普查主要数 据》, 以及《广元市教育资源普查数据》。

\section{2 城镇化特征分析}

\section{1 人口: 青壮年流失, 城乡人口结构深刻变化}

2015 年研究区净流出人口 1077.9 万人, 净流出 人口占户籍人口的比例高达 $21.0 \%$ 。以苍溪县为案 例具体分析人口流出情况(图 1): 2015 年苍溪全县 户籍人口 79.4 万人, 净流出 18.8 万人, 本地常住人口 60.6 万人, 其中城镇、农村分别为 19.4 万、 41.2 万人。 根据访谈, 全县青壮年流出比例为 $75 \%$, 其中农村 地区流失比例接近 $90 \%$ (部分进人到本地城镇)。农 村劳动力约 26 万, 其中纯粹的农业劳动力约 11 万, 基本是 60 岁以上 “不再愿意出去打工” 的老人; 另有
表 12015 年四川人口流出情况

Tab.1 Population outflow statistics at different administrative levels of Sichuan Province, 2015

\begin{tabular}{llcc}
\hline \multicolumn{1}{c}{ 地区 } & $\begin{array}{c}\text { 户籍人口 } \\
\text { /万人 }\end{array}$ & $\begin{array}{c}\text { 常住人口 } \\
\text { /万人 }\end{array}$ & $\begin{array}{c}\text { 净流出人口 } \\
\text { /万人 }\end{array}$ \\
\hline 四川省 & 9102.0 & 8204.0 & 898.0 \\
成都市 & 1155.9 & 1465.8 & -309.9 \\
地级市辖区 & 2119.6 & 1995.6 & 124.0 \\
县域(研究区内 76个) & 5143.0 & 4065.1 & 1077.9 \\
\hline
\end{tabular}

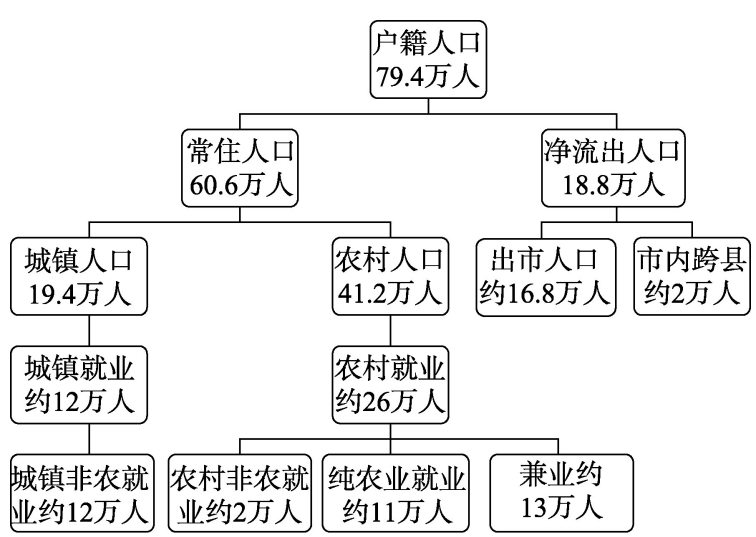

图 1 苍溪县人口结构分析示意图

Fig.1 Population structure of Cangxi County, Sichuan Province

13 万兼业劳动力, 农忙时节务农, 农闲时期到邻近 城镇打短工、做小生意。另外,农村还有 15 万非就 业人群, 主要是留守儿童、高龄老人, 以及部分丧失 劳动力(因病因残)的人群。

人口流出的影响在于: (1) 农村形成以留守老 人、留守儿童为主的特殊人口结构, 即便在城镇, 青 壮年也不多; (2)农村事实上没有 “待转移”的“富余 劳动力”, 而是以老龄劳动力为主, 处在务农与短期 打工之间摇摆的劳动力; (3) 县城 “用工荒”与 “招工 难” 的情况普遍, 老龄就业人群流动半径短 (打工不 出县), 且倾向 “打零工”为主的灵活工作方式, 这使 得每个县域劳动力市场规模都很小, 且很难找到满 足现代企业需要的年轻人。

\section{2 城镇化: 水平低增长快且增速与人口流出正相关}

四川省县域城镇化水平较低, 2000 年平均城镇 化率仅 $16.7 \%, 2015$ 年升至 $37.5 \%$, 仍明显低于四川 省平均水平 $(48.1 \%)$ 。但 $2000-2015$ 年间, 县域城镇 人口增速高于全省平均水平, 年均增速达到 $4.6 \%$, 且 明显高于成都市、地市级市辖区等城镇层级(表 2 )。

按照常规认识, 县域人口流出越多, 说明城镇吸 引力越弱。然而在四川县域城镇化中, 却呈现出人 口流出越多城镇化速度越快的相反情况。如表 3 所 
表 $22000-2015$ 年四川省各层级城镇化水平变化情况

Tab.2 Change of urbanization level at different administrative levels in Sichuan Province, 2000—2015 (\%)

\begin{tabular}{lccc}
\hline \multicolumn{1}{c}{ 层级 } & $\begin{array}{c}2015 \text { 年 } \\
\text { 城镇化率 }\end{array}$ & $\begin{array}{c}2000 \text { 年 } \\
\text { 城镇化率 }\end{array}$ & $\begin{array}{c}2000-2015 \text { 年城镇 } \\
\text { 人口年均增长率 }\end{array}$ \\
\hline 全省 & 48.1 & 27.1 & 3.9 \\
成都市 & 71.6 & 53.7 & 3.8 \\
地级市辖区 & 57.9 & 40.6 & 2.7 \\
县域(研究区内 76个) & 37.5 & 16.7 & 4.6 \\
\hline
\end{tabular}

示, 人口流出 20 万 50 万的县年均城镇人口增长率 达到 $5.6 \%$, 流出人口 10 万 20 万的县平均增速 $4.2 \%$, 流出人口 10 万以下的县年均增长率仅 $3.9 \%$ 。

\section{3 经济: 工业基础较弱, 工业化与城镇化过程关联}

不紧密

四川省县域单元工业化发展对城镇化支撑作 用不足。一是工业规模偏小, 76 县工业总产值占全 省比重只有 $20.1 \%$, 明显低于 $49.6 \%$ 的常住人口比 例, 人均工业总产值只有 3.4 万元, 远低于四川省平 均 8.5 万元的人均水平; 二是工业的就业支撑能力 弱, 制造业占非农就业比例只有 $22.9 \%$, 明显低于 $32.6 \%$ 的一般水平(全国平均), 反而是生活服务业、 建筑业比例相对高(图 2)。

四川省县域单元工业化与城镇化在统计上的 因果关系并不明显。如表 4所示, 研究区县域的工 业增速低于地市级辖区, 但城镇人口增速却远超过 该类地区。将 76 个县的工业总产值增速与城镇人 口增速进行相关性分析, 其结果趋近于 0 (图 3)。按 照传统区域经济理论, 县域经济多处于工业化中前 期阶段,需要通过工业化的发展来支撑城镇化进 程, 但四川省县域单元的实际城镇化进程并不依赖 工业化发展。

苍溪案例同样支撑这一点。2015 年县城人口 约 13 万, 县城工业园就业约 8000 人, 占就业比例仅 $10 \%$ 。与此同时, 县城商业相对繁荣, 城市发展高 度依赖消费与房地产开发, 与工业园关系不大。同 期,苍溪县城房价 6541 元 $/ \mathrm{m}^{2}$, 高于广元市中心利州 区 $\left(6491\right.$ 元 $\left./ \mathrm{m}^{2}\right)$, 而苍溪人均 GDP 只有 22940 元, 只
相当于利州区的一半(45050元)。这表明,四川县域 城镇化存在特殊路径, 与传统认识有所不同。

\section{3 城镇化机制分析}

\section{1 人口进城过程: 以留守人群为主, 教育资源和公 共服务是主要吸引力}

考察农村转移人口的主体人群,在苍溪调查发 现, 进城人群主要是农村留守的老人与儿童,进城 以生活、接受良好公共服务为主要目的, 进城过程 不依赖家庭劳动力在本地务工就业。形成了四川 省县域“留守人群进城生活”主导的城镇化模式,而 非东部沿海城市“农民进城务工”的城镇化方式。 在本地工业发育不足的情况下, 县城与重点城镇依 然人气旺盛、消费繁荣。

现场调研发现,教育是城镇吸引人口集聚的关 键力量, 以小孩进城读书、家长陪读的形式为主。 城镇人口中求学人群的比例突出, 许多地方出现了 “书包里的县城” “书包里的乡镇”等现象。以苍溪 县为例, 在校学生约占全县常住人口的 $15 \%$, 却占 县城人口的 $25 \%$ 、镇区人口的 $54 \%$ 、乡集镇人口的 61\%(图 4)。考虑陪读家长、在校老师的情况, 教育 带动城镇发展的实际比例更高, 在县域城镇化中具 有举足轻重的影响。

\section{2 城镇化动力机制: 转移支付支撑办学、劳务返还} 支撑进城生活

上文所述的城镇化模式与传统理论认知矛 盾。按照一般规律,工业化基础支撑了居民收人和 政府财政能力,从而成为居民消费、政府办学的经 费来源。人口流出地区工业基础弱, 与城镇化、就 业发展关联弱, 必然存在某种特殊因素, 支撑了上 述留守人群主导的“生活型城镇化”模式。

研究发现,地方办学经费来自政府财政,县级 财政主要来自国家转移支付。四川省县级政府的 财政能力均比较弱, 相当程度上依赖中央财政转移 支付。苍溪县 2015 年地方一般公共预算支出为

表 $32000-2015$ 年各县人口流出与城镇化速度关系情况

Tab.3 Population outflow and urbanization speed of counties in Sichuan Province, 2000-2015

\begin{tabular}{|c|c|c|c|c|c|c|}
\hline 流出规模 & 个数 & $\begin{array}{c}2015 \text { 年常住 } \\
\text { 人口/万人 }\end{array}$ & 平均规模/万人 & $\begin{array}{c}2015 \text { 年净流出 } \\
\text { 人口/万人 }\end{array}$ & $\begin{array}{l}\text { 平均净流出 } \\
\text { 人口/万人 }\end{array}$ & $\begin{array}{c}\text { 城镇人口 } \\
\text { 年均增速 } \% \%\end{array}$ \\
\hline 全省平均 & - & 8204.0 & - & 898.0 & - & 3.9 \\
\hline 县域人口流出 20 万 -50 万 & 20 & 1736.6 & 86.8 & 630.1 & 31.5 & 5.6 \\
\hline 县域人口流出 10 万 20 万 & 22 & 1318.5 & 59.9 & 322.7 & 14.7 & 4.2 \\
\hline 县域人口流出 10 万内 & 34 & 1010.0 & 29.7 & 125.1 & 3.7 & 3.9 \\
\hline
\end{tabular}


36.0 亿元, 而地方一般公共预算收人仅 4.3 亿元, 对 中央财政转移支付的依赖十分明显。在本地产业 发展不足、财政能力有限的情况下, 中央财政转移 支付支撑了教育发展。

城乡居民的收人来源, 相当部分来自于外出务 工劳动力的收人返还。根据现场调查, 县城购房与 消费的资金主要来源于乡镇村的广大居民,而他们 收人来源的 $10 \%$ 来自于农业, $20 \%$ 来自于本地打工 或生意所得, $70 \%$ 来自于异地打工返还。本地大量 流出的劳动力, 其在外收人中的相当比例被寄还给

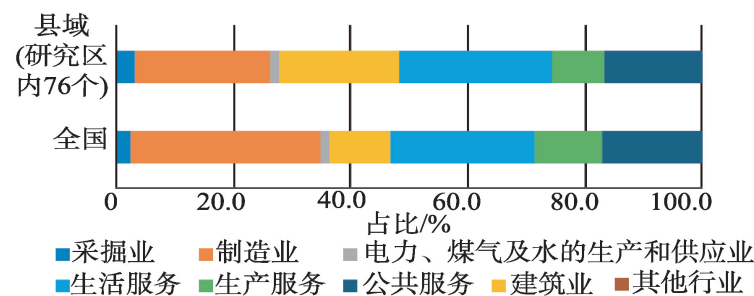

图 2 四川省县域单元与全国非农就业结构对比

Fig.2 Comparison of non-agricultural employment structures between counties of Sichuan Province and nationwide

表 $42000-2015$ 年四川省各层级 工业化与城镇化速度对比

Tab.4 Comparison of the speed of industrialization and urbanization at different administrative levels in Sichuan Province, 2000-2015 (\%)

\begin{tabular}{lcc}
\hline \multicolumn{1}{c}{ 层级 } & $\begin{array}{c}2000 \text {-2015 年工业 } \\
\text { 总产值年均增速 }\end{array}$ & $\begin{array}{c}2000 \text { - } 2015 \text { 年城镇 } \\
\text { 人口年均增速 }\end{array}$ \\
\hline 全省 & 8.1 & 3.9 \\
成都市 & 4.0 & 3.8 \\
地级市辖区 & 9.8 & 2.7 \\
县域(研究区内 76个) & 9.4 & 4.6 \\
\hline
\end{tabular}

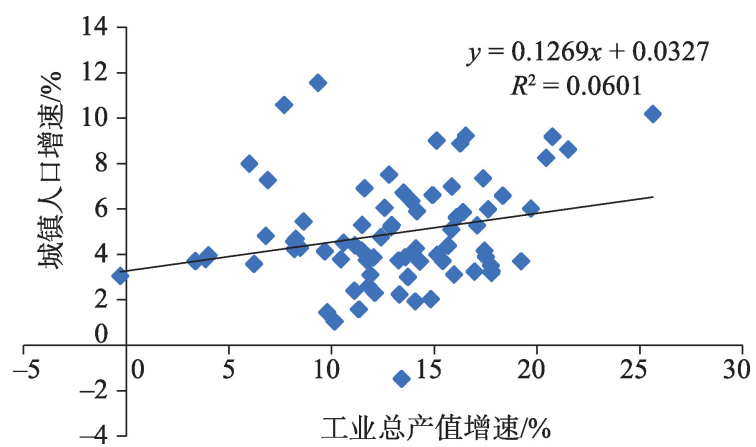

图 3 四川省各县工业总产值年增速 与城镇人口年增速关系

Fig.3 Relationship between annual growth rate of gross industrial output and urban population growth in counties of Sichuan Province
家乡的留守人群,成为本地人群进城生活的经济基 础。以苍溪县为例, 2015 年净流出人口 18.8 万, 以 外出人口人均每年返还 15000 元估算, 其总额达到 28 亿元, 占地方当年 GDP(113 亿元) 比例接近 $1 / 4$ 。

因此,财政转移支付与劳务返还等外部输血支 撑了四川省县域单元特殊的生活型城镇化模式。 如果将财政转移看作外出务工人员纳税的转移, 可 将这种城镇化机制理解为, 流出劳动力在沿海务 工,并将工作回报返还给家乡,推动了本地留守人 员进城生活, 从而形成了不同于沿海经验的城镇化 机制。研究将这种特殊机制归纳为“异地工业化带 动的本地城镇化”(图 5)。

\section{3 公共服务集中化的影响: 地形环境影响了镇村 与设施布局, 加剧了教育人群进城需求}

四川省县域多为丘陵县, 受地形限制, 耕地分 散而交通距离长, 村庄布局 “小而散”,一般一个行 政村约 200 多户, 自然村小得多。相应的乡镇布局 也呈现“小而散”的聚落特点。在人口流出的情况 下, 公共服务很容易低于设立的门槛规模, 而不得

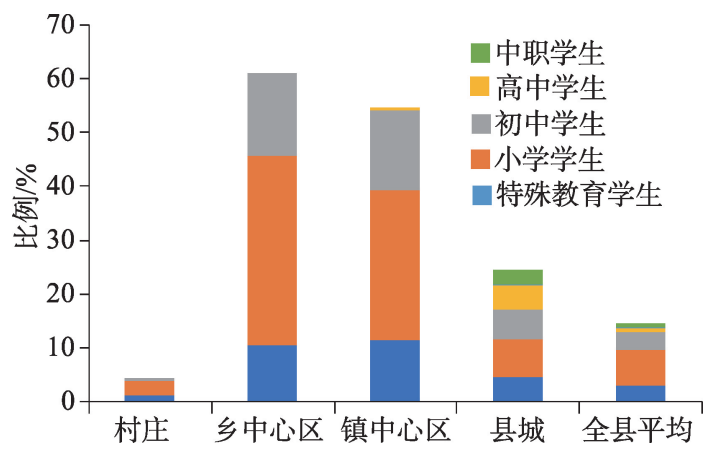

图 4 苍溪县各层级在校学生占常住人口比例

Fig.4 Proportion of school students in the resident population of all types of settlements,

Cangxi County, Sichuan Province

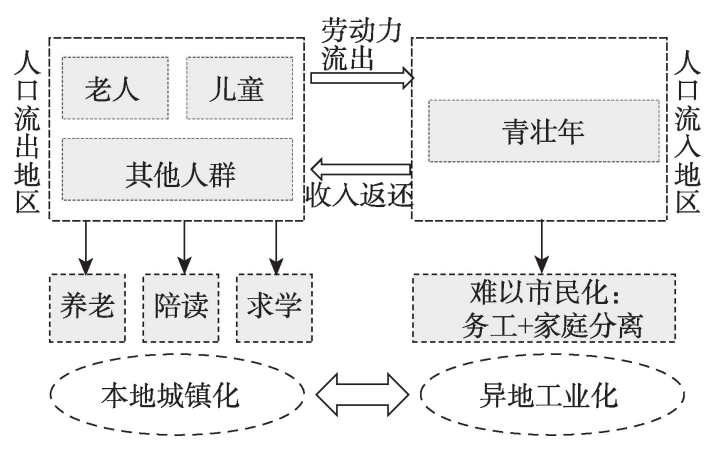

图 5 “异地工业化带动本地城镇化” 模式

Fig.5 A model of "distant industrialization driving local urbanization" 
不撤并, 教育资源因而不断向高等级城镇集中。由 于四川乡镇经济不发达, 小城镇产业基础弱, 使得 小城镇人口中学生比例很高, 乡镇也随着学校撤并 而跟着撤并。

由于地形限制, 集中后的公共服务难以便捷覆 盖广大乡村, 许多农村学生通勤距离过长, 大量基 层学生不得不进城读书, 这与平原地区情形存在明 显差别(图 6)。根据苍溪的教育普查数据统计, 大约 有 $47 \%$ 的小学生选择寄宿读书。因此,地形特点、 人口流出、办学门槛等共同导致了基层教育人群向 高等级城镇集中的趋势。

\section{4 总结与讨论}

\section{1 主要结论: 人口流出地区存在留守人群主导的 “生活城镇化”}

本文以四川省典型县域单元为案例, 对人口流 出地区的城镇化路径模式进行重新审视。研究发 现, 随着人口大量流出, 农村人口以老人、儿童为 主, 年轻劳动力明显较少。在此背景下, 传统“务工 型城镇化” 相对弱势, 留守人群的“生活型城镇化” 比例突出, 在常规城镇化过程以外, 形成了以教育 为重要方向的 “生活城镇化” 路径, 与沿海地区经验 过程截然不同。支撑生活城镇化的关键力量, 在于 外出务工人员的收人返还与政府财政转移支付, 形 成了异地工业化带动本地城镇化的特殊机制。

在此认识的基础上, 不难理解先前提到的“反 常”的城镇化特征: 在普遍缺乏支柱产业发展的背 景下, 县域人口流出越多, 相应的劳务收人返还越 多, 于是本地消费越繁荣、城镇化动力越强; 地级市 辖区内农村人口比例较低, 外出务工收人返还相对 少于县域单元, 因而出现县域城镇化速度远超过地 级市辖区的情况; 由于县城相比乡村的教育资源优 势, 农村人口大量涌人县城, 县城面临的教育需求、 购房需求远超过自身规模, 在县域人口庞大需求支 撑下, 学校 “大班制”、人口大县房价超过所在地级 市便不足为奇。

\section{2 理论思考: 传统“工业化带动城镇化”模式不完 全适用这类地区}

人口流动方面, 传统理论默认家庭与劳动力的 流动是一体的, 但事实上在中国存在大量家庭分离 情况。许多内陆省市, 劳动力大量流出, 城镇化主 体是留守人群而非务工人群。留守人群同样具有

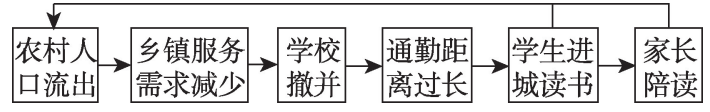

图 6 四川省县域单元“教育城镇化”模式

Fig.6 A model of "urbanization of education" at the county level in Sichuan Province

流动性, 其流动不以收人、就业为导向, 因而产生了 与传统认识截然不同的城镇化路径。这与沿海城 市经验中通过农民进城务工带动城镇发展的模式 截然不同。内陆县城一定程度上可以看作是沿海 产业区的“生活配套区”。传统理论多来自国外小 国模型, 放到中国这一大国的局部地区, 已不再完 全适用。

在沿海城市存在户籍门槛的情况下, 一些内陆 农村家庭选择劳动力在回报更高、发展空间更大的 沿海城市工作, 家滕在生活成本更低、性价比更高 的内陆城镇生活。这种以家庭分离为代价、换取家 庭生活状况改善的做法, 在中西部很多地方存在, 在一定程度上助推了留守人群的就近就地城镇 化。农民工市民化是城镇化的必然趋势, 在区域差 异短期难以消除、户籍改革难以一步到位的情况 下, 留守人群主导的生活城镇化是特定历史环境下 的产物。

\section{3 趋势分析: 当前路径不可持续,转型与管控的需} 求迫切

依靠外部输血、以留守人群为主导的城镇化模 式是难以持续的:一是人口流出存在天花板, 随着 人口回流和家庭团聚, 外出务工的收人返还必然减 少; 二是在当前经济环境下, 国家财政的补助不可 能无限增长; 三是新一代年轻人更重视生活, 不愿 意选择家庭分离的生活方式。

因此, 依靠外部输血支撑的城镇化, 是特殊发 展时期的特殊产物, 人口流出地区的快速城镇化并 不代表“后发赶超”,此类地区的长期发展必然回归 “本地产业发展, 实现自我造血”的良性过程, 发展 模式需要调整。特殊的城镇化路径导致了特殊的 城镇化现象，在新时期也将面临特殊的城镇化问 题,许多累积的矛盾需要解决。

首先, 县域快速城镇化已接近尾声, 产业空心 化的风险可能逐渐显现。农村已经没有富余劳动 力, 学龄儿童多数已进城, 城镇化的潜力已大量释 放, 未来城镇化人口增长不可能重复上一阶段高速 度。而地方房地产超前建设现象十分普遍, 几乎所 
有县城都有扩张 $2 \sim 3$ 倍的增量规划。未来房地产 与地方债务风险可能进一步加剧。

其次,农村问题复杂且越发严峻, 乡村振兴缺 乏人力资源。在人口流出、教育城镇化背景下, 农 村空心化与老龄化并发, 老人赡养问题、民生问题 不断加剧。随着年龄的更迭, 这一代老人退休后没 有新的劳动力跟进, 未来农村劳动力将面临快速减 少趋势, 而新生代农民不会务农, 农业劳动力问题 越发突出。人力瓶颈将成为 “乡村振兴” 战略实施 中最突出的困难。

\section{参考文献(References)}

[1] 仇方道, 朱传耿, 刘振. 县域城镇化发展水平评价与对策 [J]. 人文地理, 2006, 21(6): 119-123. [Qiu Fangdao, Zhu Chuangeng, Liu Zhen. Study on evaluation and countermeasures of urbanization development level of county. Human Geography, 2006, 21(6): 119-123. ]

[2] 凌篵舒, 王立, 薛德升. 江西省县域城镇化水平测度及其 分异研究 [J]. 人文地理, 2014, 29(3): 89-94. [Ling Xiaoshu, Wang Li, Xue Desheng. A study of the countylevel urbanization and its differentiation in Jiangxi Province. Human Geography, 2014, 29(3): 89-94. ]

[3] 陈明星, 陆大道, 查良松. 中国城市化与经济发展水平关 系的国际比较 [J]. 地理研究, 2009, 28(2): 464-474. [Chen Mingxing, Lu Dadao, Zha Liangsong. Urbanization and economic development in China: An international comparison based on quadrant map approach. Geographical Research, 2009, 28(2): 464-474. ]

[4] 周一星. 城市化与国民生产总值关系的规律性探讨 [J]. 人口与经济, 1982(1): 28-33. [Zhou Yixing. Discussion on the relationship between urbanization and gross domestic product. Population \& Economics, 1982(1): 28-33. ]

[5] 陈明星, 郭莎莎, 陆大道. 新型城镇化背景下京津冀城市 群流动人口特征与格局 [J]. 地理科学进展, 2018, 37(3): 363-372. [Chen Mingxing, Guo Shasha, Lu Dadao. Characteristics and spatial patterns of floating population in the Beijing- Tianjin- Hebei urban agglomeration under the background of new urbanization. Progress in Geography, 2018, 37(3): 363-372. ]

[6] 程姝. 城镇化进程中农民工市民化问题研究 [D]. 哈尔 滨: 东北农业大学, 2013. [Cheng Shu. The study of rural labors' migration in the process of urbanization. Harbin, China: Northeast Agricultural University, 2013. ]

[7] 尹鹏, 李诚固, 陈才, 等. 新型城镇化情境下人口城镇化 与基本公共服务关系研究: 以吉林省为例 [J]. 经济地 理, 2015, 35(1): 61-67. [Yin Peng, Li Chenggu, Chen
Cai, et al. Relationship between population urbanization and basic public service in the context of the new urbanization: Take Jilin Province for example. Economic Geography, 2015, 35(1): 61-67. ]

[8] 陆大道, 陈明星. 关于 “国家新型城镇化规划 (2014 2020)”编制大背景的几点认识 [J]. 地理学报, 2015, 70 (2): 179-185. [Lu Dadao, Chen Mingxing. Several viewpoints on the background of compiling the"National New Urbanization Planning (2014-2020)". Acta Geographica Sinica, 2015, 70(2): 179-185. ]

[9] 姚士谋, 陆大道, 王成新. 我国新型城镇化的若干策略问 题探讨 [J]. 现代城市, 2014, 9(4): 5-10. [Yao Shimou, Lu Dadao, Wang Chengxin. Several strategy issues of the new urbanization in China. Modern City, 2014, 9(4): 5-10. ]

[10] 李艳梅, 张雷. 中国城市化发展与重工业扩张的协整分 析 [J]. 经济地理, 2008, 28(2): 201-204, 200. [Li Yanmei, Zhang Lei. Co-integration analysis of urbanization development and heavy industry expand. Economic Geography, 2008, 28(2): 201-204, 200. ]

[11] 李强. 旅游城镇化发展模式与机制研究 [D]. 长春: 东北 师范大学, 2013. [Li Qiang. Research on the development model and mechanism of tourism urbanization. Changchun, China: Northeast Normal University, 2013. ]

[12] 吴勇. 山地城镇空间结构演变研究: 以西南地区山地城 镇为主 [D]. 重庆: 重庆大学, 2012. [Wu Yong. Study on spatial structure evolution of mountain urban: Example for southwest areas of China. Chongqing, China: Chongqing University, 2012. ]

[13] 践晓峰, 姜莉, 陈方. 云南省县域城镇化与交通优势度 的时空协同性演化分析 [J]. 地理科学, 2017, 37(12): 1875-1884. [Ji Xiaofeng, Jiang Li, Chen Fang. Spatiotemporal cooperative evolution analysis of transportation superiority and county urbanization in Yunnan Province. Scientia Geographica Sinica, 2017, 37(12): 1875-1884. ]

[14] 崔学刚, 方创琳, 李君, 等. 城镇化与生态环境耦合动态 模拟模型研究进展 [J]. 地理科学进展, 2019, 38(1): 111-125. [Cui Xuegang, Fang Chuanglin, Li Jun, et al. Progress in dynamic simulation modeling of urbanization and ecological environment coupling. Progress in Geography, 2019, 38(1): 111-125. ]

[15] 刘彦随, 杨忍. 中国县域城镇化的空间特征与形成机理 [J]. 地理学报, 2012, 67(8): 1011-1020. [Liu Yansui, Yang Ren. The spatial characteristics and formation mechanism of the county urbanization in China. Acta Geographica Sinica, 2012, 67(8): 1011-1020. ]

[16] 关兴良, 魏后凯, 鲁莎莎, 等. 中国城镇化进程中的空间 集聚、机理及其科学问题 [J]. 地理研究, 2016, 35(2): 
227-241. [Guan Xingliang, Wei Houkai, Lu Shasha, et al. Patterns and driving mechanism of spatial agglomeration during the urbanization process in China. Geographical Research, 2016, 35(2): 227-241. ]

[17] 舒小林, 齐培潇, 姜雪, 等. 旅游业影响我国西部地区新 型城镇化的因素、机理及路径研究: 基于西部地区 32 个旅游城市的数据分析 [J]. 生态经济, 2018, 34(8): 105-111, 117. [Shu Xiaolin, Qi Peixiao, Jiang Xue, et al. Analysis on the effect indicators and ways of tourism industry on new urbanization in western China: Based on 32 tourism cities' data analysis. Ecological Economy, 2018, 34(8): 105-111, 117. ]

[18] 朱高立, 王雪琪, 李发志, 等. 房地产经济对人口城镇化 与土地城镇化协调发展的作用机理: 基于中国 30 个省 会城市面板数据的经验分析 [J]. 经济地理, 2018, 38 (5): 68-77, 116. [Zhu Gaoli, Wang Xueqi, Li Fazhi, et al. The role played by real estate on the coordination between population urbanization and land urbanization: Based on the panel data of 30 cities in China. Economic Geography, 2018, 38(5): 68-77, 116. ]

[19] 欧向军, 甄峰, 秦永东, 等. 区域城市化水平综合测度及 其理想动力分析: 以江苏省为例 [J]. 地理研究, 2008, 27(5): 993-1002. [Ou Xiangjun, Zhen Feng, Qin Yongdong, et al. Study on compression level and ideal impetus of regional urbanization: The case of Jiangsu Province. Geographical Research, 2008, 27(5): 993-1002. ]

[20] 孙文慧, 高向东, 吴文钰, 等. 我国城镇化水平的省际差 异及分类研究 [J]. 西北人口, 2005(3): 1-4. [Sun Wenhui, Gao Xiangdong, Wu Wenyu, et al. Analysis and classified study on the provincial difference of the urbanization development level in our country. Northwest Population, 2005(3): 1-4. ]

[21] 王富喜, 毛爱华, 李赫龙, 等. 基于熵值法的山东省城镇 化质量测度及空间差异分析 [J]. 地理科学, 2013, 33 (11): 1323-1329. [Wang Fuxi, Mao Aihua, Li Helong, et al. Quality measurement and regional difference of urbanization in Shandong Province based on the entropy method. Scientia Geographica Sinica, 2013, 33(11): 1323-1329. ]

[22] 张善余. 我国区域城市化发展水平的差异分析 [J]. 人 口学刊, 2002(5): 37-42. [Zhang Shanyu. Analysis on the difference of the development level of regional urbanization in China. Population Journal, 2002(5): 37-42. ]

[23] 刘盛和. 中国城市化水平省际差异的成因探析 [J]. 长 江流域资源与环境, 2004, 13(6): 530-535. [Liu Shenghe. Causal analysis on the regional disparities of urbanization in China. Resources and Environment in the Yangtze Basin, 2004, 13(6): 530-535. ]

[24] 张立生. 县域城镇化时空演变及其影响因素: 以浙江省 为例 [J]. 地理研究, 2016, 35(6): 1151-1163. [Zhang Lisheng. Spatial-temporal evolution of county urbanization and its influencing factors in Zhejiang Province. Geographical Research, 2016, 35(6): 1151-1163. ]

[25] 刘涛, 齐元静, 曹广忠. 中国流动人口空间格局演变机 制及城镇化效应: 基于 2000 和 2010 年人口普查分县数 据的分析 [J]. 地理学报, 2015, 70(4): 567-581. [Liu Tao, Qi Yuanjing, Cao Guangzhong. China's floating population in the 21st century: Uneven landscape, influencing factors, and effects on urbanization. Acta Geographica Sinica, 2015, 70(4): 567-581. ]

[26] 彭羽, 常黎丽. 湖南省县域城镇化时空格局及其经济发 展相关性研究 [J]. 经济地理, 2013, 33(8): 73-78. [Peng Chong, Chang Lili. Spatial-temporal pattern of county urbanization and its relationship with economic development in Hunan Province. Economic Geography, 2013, 33 (8): 73-78. ]

[27] 刘阳. 西部欠发达地区县域城镇化研究 [D]. 广州: 华南 理工大学, 2013. [Liu Yang. Study on the urbanization of county in underdeveloped regions of Western China: Suiyang County, Guizhou Province as an example. Guangzhou, China: South China University of Technology, 2013. ]

[28] 李富田. 西部地区县域城镇化的现状与问题分析 [J]. 软科学, 2015, 29(5): 37-40, 54. [Li Futian. The present situation and the problem analysis of the county urbanization in the west area. Soft Science, 2015, 29(5): 37-40, 54. ]

[29] 唐蜜, 肖䂞. 欠发达地区人口大县城镇化动力机制分析 [J]. 农业经济问题, 2014, 35(8): 100-109, 112. [Tang Mi, Xiao Lei. Analysis on the dynamic mechanism of urbanization in the large population counties in Underdeveloped Areas. Issues in Agricultural Economy, 2014, 35 (8): 100-109, 112. ] 


\title{
Re-examination of urbanization paths and mechanism in population outflow areas: \\ A case study of counties in Sichuan Province
}

\author{
XIAO Lei, PAN Jie \\ (China Academy of Urban Planning \& Design Western Branch, Chongqing 401120, China)
}

\begin{abstract}
Taking the county unit of Sichuan Province as the research object, the characteristics and mechanism of urbanization in population outflow areas are discussed. The study found that: different from the experience of coastal cities, urbanization of counties in Sichuan Province is dominated by living-oriented type, and the main driving forces for the urbanization of rural population are consumption and education demands. The main body of the newly urbanized population is the left-behind population after considerable labor losses, and their financial resource of living in cities depends to a large extent on the remittance sent back by migrant workers. Industry shows weak support to urbanization, forming a special mode of urbanization, that is, remote industrialization driven local urbanization, which leads to many unique phenomena. For example, the more population outflow, the faster urbanization speed; counties continued to grow and flourish without manufacturing development; and the urbanization speed of counties is faster than that of city. Based on these new findings, this article discussed the relevant understanding of urbanization mechanism and the prospect of long-term trend and potential problems of urbanization development in such areas.
\end{abstract}

Keywords: urbanization mechanism; county level; population outflow; Sichuan Province 